\title{
Citizen Perceptions of E-Government in the Kurdistan Region of Iraq
}

\author{
Khosro Mohammad Ahmad \\ University of Canberra \\ khosro_araki@yahoo.com \\ John Campbell \\ University of Canberra \\ john.campbell@canberra.edu.au
}

\begin{abstract}
Despite increasing investment by governments globally, citizens in some countries are less willing to engage with e-government innovations. While previous studies have examined what might encourage citizens to adopt e-government services more broadly, further research is required to understand those factors that impede or enable e-government adoption in countries that have, or are in the process of, transitioning to democratic self-rule. This study is the first to investigate citizen attitudes to e-government adoption in the Kurdistan Region of Iraq and thus provides insight into the factors affecting the adoption of e-government within an emerging democratic state. This study also distinguishes between two types of egovernment services; informational and transactional. Thus a research model with two elements is developed and tested; one for intention to use informational e-government and one for intention to use transactional e-government. Data were collected through a survey administered to university students and non-academic employees in Arbil the capital city of Kurdistan, and analysed using structural equation modelling. Perceived usefulness, social influence, trust in government and perceived risk were found to be significantly and directly associated with the intention to use both kinds of e-government services. However perceptions of ease of use, information quality and trust in the Internet were not significant.
\end{abstract}

Keywords: e-government adoption; Kurdistan Region; informational e-government; transactional e-government; intention to adopt

\section{Introduction}

The use of the Internet to communicate and transact with customers has not been limited to commercial endeavours only. Public sector organizations worldwide have also gained significant advantages by employing Internet technology to support government activities, and to communicate with citizens and other stakeholders (Kumar et al., 2007). E-government is defined as the "use of information technology to enable and improve the efficiency with which government services are provided to citizens, employees, businesses and agencies" (Carter \& Belanger, 2005, p.5). It has been argued that e-government can generate substantial benefits for governments and citizens alike, and provide important infrastructure for the improvement of both societal and economic conditions in developing countries (Gregor et al., 2013). Through e-government initiatives government agencies in developing countries can improve service delivery and reduce costs, while citizens also benefit from greater transparency and increased access options to key government services (Belanger \& Carter, 2008; Featherman \& Pavlou, 2003; Lean et al., 2009; Ndou, 2004; Wang \& Shih, 2009).

The success of e-government initiatives is highly dependent upon citizens' willingness to switch from traditional methods of engaging with government to online channels. This is particularly important because the use of e-government services requires voluntary support, and the introduction of online services does not usually bring traditional methods of government/ citizen engagement to an end (Alsaghier et al., 2009; Lu et al., 2011; Tung \&Rieck, 2005). Despite the availability of e-government services, citizens may continue using the traditional engagement methods which may diminish the overall success of e-government 
initiatives and even lead to their failure (Guha \& Chakrabarti, 2014). Further, the success of IT developments in developing countries more broadly is reliant on contextual factors relating to culture, region and country (Avgerou \& Walsham, 2000). Thus, understanding citizens' perceptions towards e-government and identifying the factors that motivate their acceptance of this technology is an important step towards successful e-government implementation in particular cultural and country contexts.

There are a number of barriers that may inhibit e-government initiatives from reaching their potential in both developed and developing countries including a lack of infrastructure, skills, strategies, policies, and financial resources (Basu, 2004; Dada, 2006; Ebrahim \& Irani, 2005; Lam, 2005; Ndou, 2004). These challenges bring our focus to the building blocks of egovernment which are those elements necessary to prepare a nation and its citizens for egovernment implementation particularly for governments in developing economies (Belanger \& Carter, 2008; Bwalya \& Mutula, 2014; Gupta \& Gupta, 2008; Kanat, 2009; Kumar et al., 2007). Further, progress towards e-government services in developing countries has been slower and less effective than in developed countries (Kamal et al., 2013). Like any other form of new technology, no matter how well-designed e-government services are, they will not succeed in realizing promised benefits if citizens are unwilling to adopt them and shift from offline to online engagement. In this regard, Gauld et al. (2010, p.178) stated that "even apparently successful projects in terms of technological and project development may face 'user failure' if potential customers, employees, or citizens simply do not use the system, something that is surprisingly common, suggesting that it is at least sensible to give some regard to intended end users' views on technology development and use".

This study is the first to explore citizens' behavioural intentions towards the adoption of egovernment services in the Kurdistan Region of Iraq. In addition to its contextual significance, we also seek to make theoretical and methodological contributions to the extant e-government literature by distinguishing between citizens' intentions to use e-government for accessing information and conducting transactions. This distinction is lacking from many e-government studies despite empirical evidence showing that these two kinds of services have different implications with transactional e-government considered more complicated and more risky for citizens since it usually requires the exchange of personal and financial information with government agencies (Kumar et al., 2007; Vassilakis et al., 2005).

\section{Study Context}

Kurdistan is an autonomous region located in the north of the Republic of Iraq. The region borders Iran to the east, Turkey to the north, Syria to the west and the rest of Iraq to the south (see Figure 1). The population is estimated to beapproximately 5 million with almost $50 \%$ aged below 20 years of age. Kurdistan occupies approximately 40,643 square kilometres which is four times the area of Lebanon and larger than the Netherlands (www.krg.org). There are three main governorates in the region namely Duhok, Arbil, and Sulaymaniyah with Arbil being the capital city of the region which is also called Hawler by local people.

The current government consists of a coalition of several political parties that reflect the diversity of the Region's people, who are Chaldeans, Assyrians, Turkmen, Yazidis and Kurds who live together in peace. The main language in Kurdistan is Kurdish which comes from the Indo-European family of languages, and has two main dialects, Sorani and Kurmanji. The Sorani Kurdish dialect uses Arabic script while the Kurmanji Kurdish dialect is written in Latin script. Sorani is spoken in the cities of Arbil and Sulaymaniyah, while Kurmanji is spoken in Duhok. There are also other languages in the region such as Turkmani, Arabic, Armenian, and Assyrian which are spoken by their respective communities. 


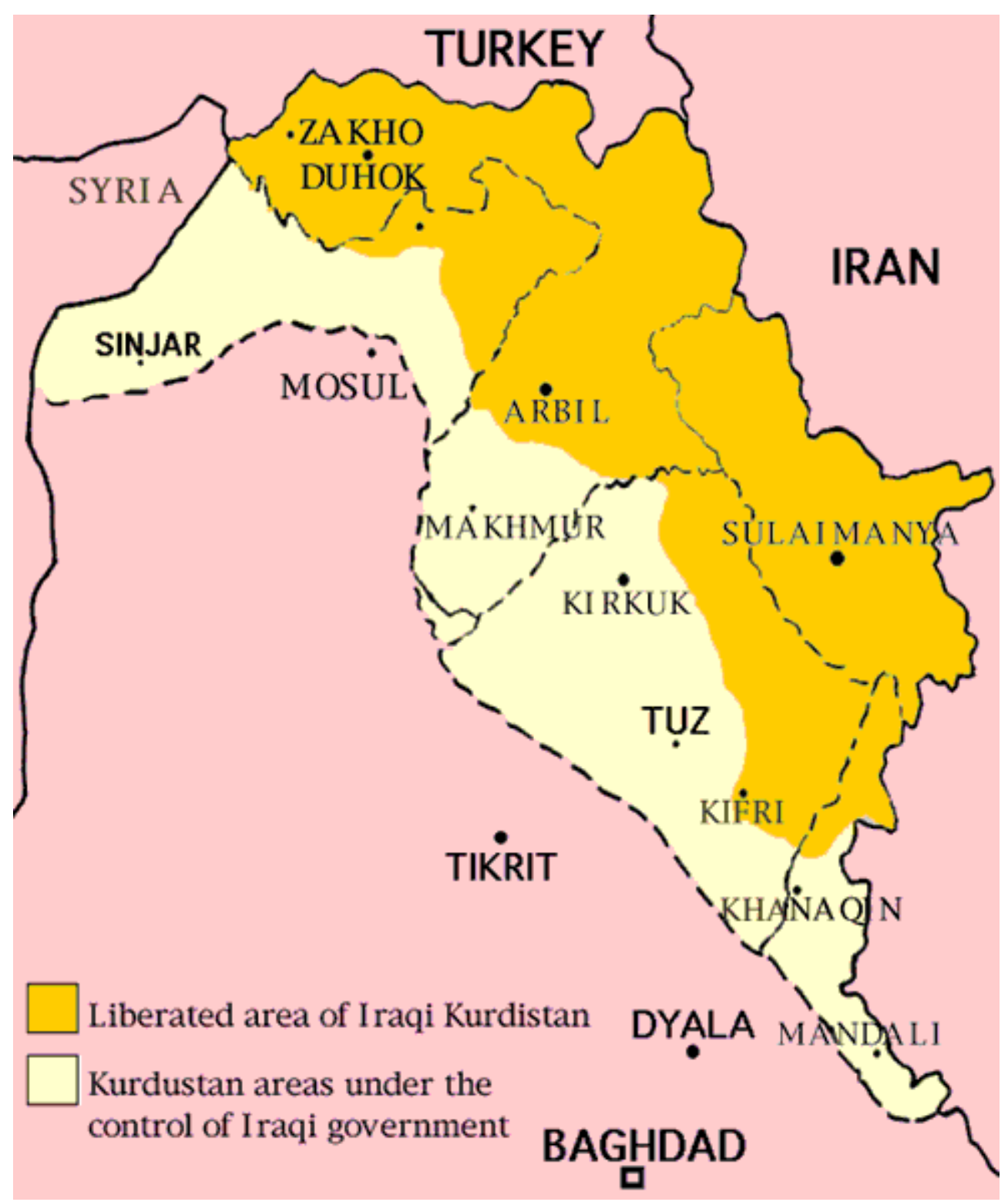

Figure 1: Geographical map of Kurdistan (source: www.institutkurde.org).

Due to years of internal conflict with the previous Iraq regime led by Saddam Hussein and the more recent civil war, the Kurdistan region remained underdeveloped economically and isolated from the rest of the world. However, since the end of Saddam Hussein's regime in 2003, the region has undergone substantial reconstruction and has experienced significant economic growth. The Kurdistan government (KRG) is determined to promote democracy in the region and to develop the quality of life of its inhabitants (www.krg.or). One area that the KRG is particularly interested in is the implementation of e-government to establish modernized government with the aim of fostering transparent governance, building a stronger relationship with its citizens, and more effective delivery of basic services (KRG IT Academy 2009). To achieve this, the KRG developed a five-year plan (2011-2015) to prepare the region for e-government implementation. However, citizens' perception about e-Government has not yet been explored in the region and no study has yet been conducted to examine whether citizens are willing to adopt e-government services, and what factors might impact their decision. 


\section{Theoretical Framework}

\subsection{Information and transaction based e-government}

There are two key service types provided by e-government; informational and transactional (Reddick, 2005; Carter \& Belanger., 2004). That is, government websites can be used to either obtain information or conduct transactions online. Informational e-government is the use of government websites to obtain information such as opening hours, download forms, or to obtain government contact details. In using this type of e-government the interaction between users and government agencies is a one-way interaction, and users do not have to provide any personal or financial information to receive the service (Almahamid et al., 2010; Chatfield \& Alhujran, 2009; Horst et al., 2007). Transactional e-government, in comparison, is the use of government websites to conduct transactions with government online (Irani et al., 2006; Reddick, 2005). This type of online service involves a two-way interaction and typically allows users to conduct an entire task online such as renewing a licence or car registration, applying for government jobs, or paying taxes (Chatfield \& Alhujran, 2009). Reddick (2005, p.41) argued that "this stage will empower citizens to deal with government online anytime, saving hours of paperwork, the inconvenience of travelling to a government office, and time spent waiting in line". Unlike informational e-government, transactional e-government often requires that users provide personal or financial information to the government department thus making these services more complex and potentially more risky (Chatfield \& Alhujran, 2009; Horst et al., 2007; Irani et al., 2006). In this regard Horst et al. (2007, p.1838) stated that "the risks of electronic services on the transactional level are more profound than at the informational level". It is due to these differences that e-government researchers have suggested that citizens are more likely to adopt e-government for informational purposes only (Gauld et al., 2010; Kumar et al., 2007; Vassilakis et al., 2005). Therefore, it is important to distinguish between informational and transactional e-government when investigating citizens' acceptance behaviour. This distinction enables researchers and government authorities to better understand the broad types of services particular citizens are willing to adopt, and to specifically identify the factors that are associated with intention to adopt either of these e-government service types.

Despite this importance, a review of e-government literature revealed that this distinction has been widely neglected by e-government researchers. In this regard, Carter and Belanger (2004) argued that future studies must distinguish between citizens' intention to use egovernment systems to gather information as well as their intention to conduct online transactions. Consequently, the current study distinguishes between intention to use both informational and transactional e-government services.

\subsection{Intention to adopt e-government services}

The concept of e-government adoption by citizens has been defined differently by various researchers (Kumar et al., 2007). Some have described it as the 'intention' (Carter \& Belanger, 2005), and others have described it as the 'willingness' (Gilbert et al., 2004) to use egovernment services. Kumar et al. (2007, p.69) described e-government adoption as "a simple decision of using, or not using, online services". Consistently, e-government adoption, for the purpose of the current study, is defined as citizens' intention/ willingness to use government websites for informational and transactional purposes. Note that willingness and intentions are used interchangeably in this study. The reason for measuring intention and not actual usage was because e-government in Kurdistan is an emerging phenomenon and Kurdistan's citizens have little to no experience with accessing e-government services. Therefore, this study was conducted to discover whether citizens in Kurdistan are willing to adopt e-government services when they become available (Mkude \&Wimmer, 2015). Previous studies have shown that intention to use is a strong predictor of actual usage (Ajzen, 1991; Belanger \&Carter, 2008; Chau \& Hu, 2001; Chu et al., 2004; Venkatesh et al., 2003). 


\subsection{Technology adoption models}

Various models have been developed by researchers and practitioners to understand users' acceptance of new technologies across various disciplines such as sociology, psychology and human behaviour (Venkatesh et al., 2003). Innovation Diffusion Theory was developed by Rogers (1962) and originated from sociology. The Theory of Reasoned Action (Fishbein \& Ajzen, 1975) and its extensions; Theory of Planned Behaviour (Ajzen, 1991) and Decomposed Theory of Planned Behaviour (Taylor \& Todd, 1995), and the Motivational Model (Deci, 1972) originated from psychology. The Technology Acceptance Model was developed by Davis (1989) to explain the adoption of information technology in the workplace and was later extended to the Technology Acceptance Model 2 (Venkatesh \& Davis 2000). The Model of PC Utilization (Triandis, 1971) and Social Cognitive Theory (Bandura, 1986) were both contributed from the human behaviour discipline. Finally, the Unified Theory of Technology Acceptance and Use (Venkatesh et al., 2003) was developed by integrating the most important elements of these previous models.

Due to contextual differences there is no general model that can be used to explain egovernment adoption behaviour (Kumar et al., 2007). Consequently, e-government researchers have tried to develop their own models by adapting important constructs from existing technology adoption models. Moreover, there are some factors that are thought to be important for determining e-government adoption behaviour which are not adequately considered by existing technology adoption models. For instance, risk and trust are perceived to be significant factors in explaining citizens' e-government adoption behaviour, however they are both notably absent from the models discussed above (Belanger \& Carter, 2008; Carter \& Belanger, 2004; Delafrooz et al., 2011; Featherman \& Pavlou, 2003; Gefen, 2003; Hung et al., 2006; Lu et al., 2011; Mayer et al., 1995; McKnight \&Chervany, 2002; Schaub \& Carter, 2005).

\section{Research Model}

Considering the characteristics of the study particularly the contextual newness of the phenomenon for Kurdistan citizens, several variables were adapted from existing studies. As discussed above, this study distinguished between intention to use informational $\mathrm{e}$ government and intention to use transactional e-government. Therefore, the research model also reflects these two elements (see Figure 2). The first model element was designed to investigate citizens' behavioural intentions towards informational e-government while the second section was designed to investigate citizens' behavioural intentions towards transactional e-government. Perceived usefulness (PU), perceived ease of use (PEOU), facilitating conditions (FC), social influence (SI), perceived information quality (PIQ), compatibility (COMPT), trust in government (TIG), trust in the Internet (TII), and perceived risk (PR) were adapted as independent variables and behavioural intention (BI) was adapted as the dependent variable for both e-government service elements. 


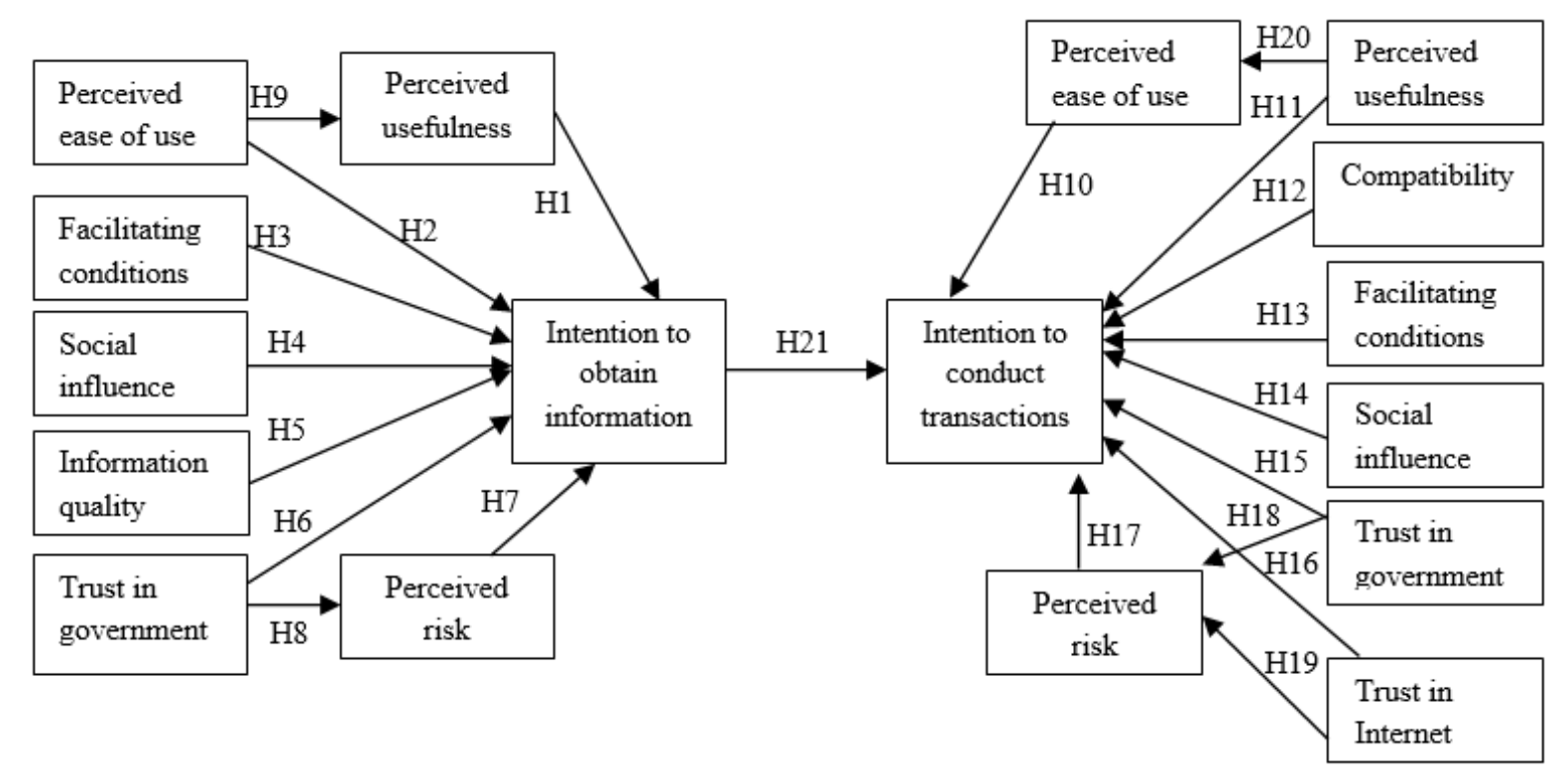

Figure 2. Hypothesized research model

\subsection{Hypothesis Development}

\subsubsection{Perceived usefulness}

This variable was adapted from the Technology Acceptance Model (TAM) and was defined as "the prospective user's subjective probability that using a specific application system will increase his or her job performance within an organizational context" (Davis et al., 1989, p. 985). TAM posits that PU is associated with the intention to use new technology both directly and indirectly through its positive effect on attitude(Davis, 1989). Studies in the e-government domain have also found PU to be a significant determinant of intention to use e-government services (Chu et al., 2004; Featherman \& Pavlou, 2003; Kumar et al., 2007; Lin et al., 2011; Schaupp \&Carter, 2005; Wangpipatwong et al., 2008). PU in the context of e-government and this study is defined as the degree to which citizens believe using government websites to access information and conduct transactions will be useful. PU was hypothesized to have a direct and positive relationship with intention to use both informational and transactional e-government services (hypotheses 1 and 11).

\subsubsection{Perceived ease of use}

This construct was also adapted from TAM and was defined as "the degree to which the prospective user expects the target system to be free of effort" (Davis et al., 1989, p.985). TAM posits that PEOU only indirectly predicts intention to use through its positive association with attitude and perceived usefulness. However, e-government studies have suggested that in addition to its indirect relationship with intention to use, PEOU can directly predict intention to use e-government services (Chu et al., 2004; Featherman \& Pavlou, 2003; Fu et al., 2006; Kumar et al., 2007; Lin et al., 2011; Schaupp \& Carter, 2005; Wang, 2002; Wangpipatwong et al., 2008). Due to empirical evidence regarding its importance in predicting intentions to use, this variable was adapted in this study and was designed to measure participants' perception regarding the ease of using government websites to access information and conduct transactions. PEOU was hypothesized to have a significant positive association with intention to use both informational and transactional e-government, directly as well as indirectly through its positive relation with perceived usefulness (hypotheses 2, 9, 10 and 20).

\subsubsection{Facilitating conditions}

This construct was adapted from the Unified Theory of Acceptance and Use of Technology (UTAUT) and was defined as the degree to which participants believe they have the means such as the hardware and software necessary to access government websites to obtain information 
and conduct transactions. UTAUT posits that FC is directly associated with the actual usage (Venkatesh et al., 2003). In this study, FC was hypothesized to have a positive relationship with intention to use both informational and transactional e-government services (hypotheses 3 and 13).

\subsubsection{Social influence}

This variable was also adapted from the UTAUT model which defined SI as "the degree to which an individual perceives that important others believe he or she should use the system" (Venkatesh et al., 2003, p.451). social influence has been found to be directly associated with the intention to use a new system (Al Awadhi \& Morris, 2008; Al-Shafi \& Weerakkody, 2010; Chu et al., 2004; Lee, 2009; Schaupp \& Carter, 2005; Suki \& Ramayah, 2010; Yaghoubi et al., 2010). SI was defined, in the context of this study, as the degree to which participants believe that people who are important to them, such as friends and families, will have an influence on their decision to use e-government services for informational and transactional purposes. SI was hypothesized to have a significant positive relationship with intention to use both informational and transactional e-government services (hypotheses 4 and 14).

\subsubsection{Compatibility}

Compatibility was one of the five characteristics of an innovation that Rogers (1983) suggested would have a positive effect on individuals' decisions to adopt an innovation. Compatibility reflects an individual's perception about the congruence of a technology with his/ her values, beliefs and lifestyle. Support has been found in the e-government literature regarding the importance of this variable in influencing users' intention to adopt e-government (Carter \& Belanger, 2004; Carter \& Belanger, 2005; Fu et al., 2006; Schaupp \& Carter, 2005; Suki \& Ramayah, 2010). Compatibility was deemed to be more relevant to transactional e-government because this type of e-government requires a significant change in the way people interact with government compared to informational e-government. Thus compatibility was hypothesized to have a significant positive relationship with participants' intention to use transactional egovernment (hypothesis 12).

\subsubsection{Perceived information quality}

This variable was adapted from DeLone and McLean (1992) and measures citizens' perception about the quality of the information that is provided by state government agencies on their websites. According to DeLone and McLean (1992) the quality of the information that is provided on government websites can be assessed in terms of accuracy, relevance, precision, reliability, completeness, and currency. The e-government literature suggests that users' perceptions about the quality of information they receive can have a significant impact on their behavioural intention to use government websites as a source of information (Almahamid et al., 2010; Al-Shibly, 2011; Lin et al., 2011; Prybutok et al., 2008). Therefore, this construct was integrated in the informational part of the model only and was hypothesized to have a direct and positive relationship with citizens' intention to use government websites to seek information (hypothesis 5).

\subsubsection{Trust in the government and the Internet}

Mayer et al. (1995, p.712) defined trust as "the willingness of a party to be vulnerable to the actions of another party based on the expectations that the other will perform a particular action important to the trustor, irrespective of the ability to monitor or control that other party". Empirical support has been found for trust (both in the government and the Internet) as a determinant of citizen adoption of e-government services (Belanger \& Carter, 2008; Carter \& Belanger, 2005; Horst et al., 2007; Schaupp \& Carter, 2005). Trust in the government is defined as the extent to which citizens believe government agencies can be trusted in carrying out online transactions with them (Carter \& Belanger, 2005; Pavlou, 2003). Therefore, the current study hypothesized that trust in the government will have a positive and direct association with citizens intention to adopt informational and transactional e-government (hypotheses 6 and 15). Moreover, trust in the government was also hypothesized to indirectly 
associate with the intention to use through its negative relation with perceived risk (hypotheses 8 and18).

Trust in the internet is more relevant to transactional e-government because informational egovernment does not require users to provide personal or financial information and thus it is unlikely that users would be concerned about the safety of the Internet. For transactional egovernment, Horst et al. (2007) argued that citizens must not only trust the government but also the infrastructure through which online transactions are performed: the Internet. Thus, trust in the Internet was hypothesized to associate with the intention to use transactional egovernment both directly and indirectly through its negative association with perceived risk (Hypotheses 16 and 19).

\subsubsection{Perceived risk}

Risk is generally defined in terms of an individual's belief about the possibility of gaining or losing something as a result of a particular action (Horst et al., 2007; Mayer et al., 1995; Pavlou, 2003). Studies have shown that perceived risk plays an important role in determining citizens' intention to use e-government services (Kumar et al., 2007; Lu et al., 2011; Schaupp \& Carter, 2009). In the context of e-government, Featherman and Pavlou (2003, p.454) defined perceived risk as "the potential for loss in the pursuit of a desired outcome of using an $\mathrm{e}$ service". Perceived risk was integrated in both e-government service elements of our research model, and was defined as the extent to which participants believed using government websites to collect information and to conduct transactions would be risky. Therefore, this study hypothesized that perceived risk would have a negative and direct association with the intention to use e-government services for both informational and transactional purposes (hypotheses 7 and 17).

\subsubsection{Behavioural intention}

As discussed earlier, this study was conducted on a perceptual basis due to the newness of egovernment concepts in Kurdistan and its citizens' comparative lack of prior experience. Thus, behavioural intentions to use informational and transactional e-government were used as dependent variables. This study also hypothesized that there would be a positive relationship between intention to use informational e-government with intention to use transactional egovernment (hypothesis 21). The rationale for this was because informational services are typically introduced before transactional services. Therefore, it was decided to examine this relationship more closely to see whether the intention to use government websites for informational access leads theintention to use government websites for transactional purposes as well.

\section{Research Methodology}

The survey instrument incorporating the constructs discussed above was developed initially in English and then translated into Kurdish by an independent translator. This Kurdish version was then translated back to English by another translator. The two versions were then compared in order to resolve any differences in meaning or expression. The final Kurdish version was then used for the main study (See Appendix 1 for the English version of the questionnaire. The Kurdish version can be provided on request). This research was conducted in accordance with the ethical research procedures and guidelines provided by the Committee for Ethics in Human Research at the University of Canberra (approved project 11-100).

University students and academic and non-academic staff have been widely used by egovernment researchers in prior studies (AL Awadhi \&Morris, 2008; Belanger \&Carter, 2008; Carter \& Belanger, 2004a; Featherman \& Pavlou, 2003; Huang et al., 2002; Lu et al., 2011; Schaub \& Carter, 2005; Schaub \& Carter, 2009; Suki \& Ramaya, 2010). Thus data were collected through a survey questionnaire administered by the first author to undergraduate university students and non-academic university staff. These participants were targeted primarily because of their educated backgrounds and the newness of e-government concepts to ordinary citizens of Kurdistan (Zhao et al., 2014). Although university students and staff 
were also believed to be inexperienced with regard to e-government services, previous studies have reported that educated citizens are more likely to become early adopters of e-government services (Huang et al., 2002; Lu et al., 2011; Suki \& Ramayah, 2010; Wangpipatwong et al., 2008). Subsequently questionnaires were distributed to students enrolled in Engineering, Education, Administration and Law Faculties located within Salahaddin University. While non-academic staff were recruited from all departments across the university. A total of 670 questionnaires were distributed of which 548 completed and usable questionnaires were obtained; a response rate of $81 \%$. The data were analysed using path analysis in Structural Equation Modelling.

\section{Results}

\subsection{Participant Demographics}

Demographic characteristics of the participants are summarized in Table 1. As demonstrated in the table, there were no significant difference in the number of male and female respondents; male $52 \%$ and female $48 \%$. Since the majority of participants in this study were undergraduate university students almost $80 \%$ were younger than 24 years. In terms of experience with computers, surprisingly more than $50 \%$ indicated having less than three years of experience. This number was even higher for internet experience (72\%). When asked whether they had visited a government website prior to participating in this study, more than half answered 'No' and 43\% indicated that they had. Overall it can be concluded that participants in this study were young with little experience with computers and the internet.

\begin{tabular}{|c|c|c|c|}
\hline \multicolumn{2}{|r|}{ Demographics } & Frequency & Percent \\
\hline \multirow[t]{2}{*}{ Sex } & Male & 285 & 52 \\
\hline & Female & 263 & 48 \\
\hline \multirow[t]{6}{*}{ Age } & $15-19$ & 63 & 11.5 \\
\hline & $20-24$ & 358 & 65.3 \\
\hline & $25-29$ & 83 & 15.1 \\
\hline & $30-34$ & 22 & 4 \\
\hline & $35-39$ & 12 & 2.2 \\
\hline & 40 and above & 10 & 1.8 \\
\hline \multirow{5}{*}{$\begin{array}{l}\text { Computer } \\
\text { experience }\end{array}$} & Less than 1 year & 111 & 20.3 \\
\hline & 1 to 3 years & 209 & 38.1 \\
\hline & 4 to 6 years & 148 & 27 \\
\hline & 7 to 9 years & 58 & 10.6 \\
\hline & More than 10 years & 22 & 4 \\
\hline \multirow{5}{*}{$\begin{array}{l}\text { Internet } \\
\text { experience }\end{array}$} & Less than 1 year & 272 & 49.6 \\
\hline & 1 to 3 years & 178 & 32.5 \\
\hline & 4 to 6 years & 67 & 12.2 \\
\hline & 7 to 9 years & 21 & 3.8 \\
\hline & More than 10 years & 10 & 1.8 \\
\hline \multirow[t]{2}{*}{ Prior website visit } & Yes & 236 & 43.1 \\
\hline & No & 312 & 56.9 \\
\hline
\end{tabular}

Table 1. Demographic profile of participants

\subsection{Data Analysis and Results}

Prior to performing statistical analysis, appropriate measures were undertaken to clean and prepare the collected data. The results revealed that the data was both reliable and valid. However, the data violated an important assumption to which the majority of statistical techniques are sensitive; normality. That is, for the majority of variables in this study the data were bimodal. To overcome this problem the data were transformed into dichotomized nominal variables with only two categories ('0' or ' 1 ', 'yes' or 'no') using a Median split approach. Following this, frequencies were produced for responses and the results revealed 
that more than $70 \%$ of participants indicated having the intention to adopt e-government services (73\% informational and 79\% transactional).

Path analysis was conducted to test the overall model; once for informational (Figure 3) and once for transactional (Figure 4). When performing path analysis sometimes the input model does not fit the data well, therefore modifications need to be applied to the model (Berry \& Welsh, 2010; Gefen et al., 2000). This was the case in the current study. Thus, modifications were applied to the model until it fit the data which resulted in the removal or addition of some relationships. It is important to mention that demographic characteristics were also included in the path analysis to test their direct relationship with the intention to use, although initially they were not hypothesized to be related. The results indicated that previous experience with government websites (prior visit) was the only important demographic to have a relationship with the intention to use both e-government services. For informational e-government it was both direct and indirect through its positive association with facilitating conditions and trust in government and negative association with perceived risk. For transactional e-government, however, it was only indirect through its positive relationship with compatibility and trust in government. This suggests that experience with government websites is likely play a role in determining users' e-government adoption behaviour. Age of participants was also shown to be positively associated with the intention to adopt transactional e-government suggesting that older participants in this study were more likely to adopt transactional e-government.

Figure 3 shows that the model containing the significant pathways explained $23 \%\left(\mathrm{R}^{2}=.23\right)$ of the variance in the intention to use informational e-government. Facilitating conditions $(\beta=$ $0.25, p<0.001)$, perceived usefulness $(\beta=0.17, p<.001)$, trust in government $(\beta=0.12, p<$ o.001), perceived risk $(\beta=-0.12, p<0.01)$, and social influence $(\beta=0.11, p<0.01)$ were all directly and significantly associated with the intention to use informational e-government. Perceived ease of use was found to be only indirectly associating with the intention to use through its positive and significant relationship with perceived usefulness $(\beta=.37, p<0.001)$. Perceived information quality was found to have no direct association with the intention to use and its relationship was positively mediated by trust in government $(\beta=0.35, \mathrm{p}<0.001)$ and perceived usefulness $(\beta=0.14, p<0.01)$. In addition to its direct association, facilitating conditions was found to also indirectly encourage citizens to visit government websites through its positive association with perceived ease of use $(\beta=0.31, p<0.001)$. Thus hypotheses 1, 3, 4, 6, 7, 8 and 9 were supported and hypotheses 2 and 5 were rejected.

As for the transactional model, Figure 4 shows that the final fitted model explained $24 \%\left(\mathrm{R}^{2}=\right.$ .24) of the variance in the intention to adopt transactional e-government. Compatibility $(\beta=$ $0.22, p<0.001)$, perceived usefulness $(\beta=0.20, p<0.001)$, social influence $(\beta=0.15, p<0.001)$, trust in government $(\beta=0.13, \mathrm{p}<0.001)$ and perceived risk $(\beta=-0.09, \mathrm{p}<0.05)$ wereall directly and significantly associated with the intention to use transactional e-government. Facilitating conditions was found insignificant, both directly and indirectly, in associating with the intention to use. Trust in the internet was found to only indirectly associate with the intention to use through its positive relationship with trust in the internet and negative relation with perceived risk. In addition to its direct association with the intention to use, compatibility was found to be positively associated with perceived usefulness $(\beta=0.17, p<0.001)$, perceived ease of use $(\beta=0.33, p<0.001)$, trust in the government $(\beta=0.22, p<0.001)$, and trust in the internet $(\beta=.30, p<0.001)$. Surprisingly the results also suggested that Age of the participants could have a positive but weak association with their intention to adopt transactional egovernment services ( $\beta=0.09, \mathrm{p}<0.05)$. Thus, hypotheses 11, 12, 14, 15, 17, 18, 19, 20 and 21 were supported and hypotheses 10,13 and 16 were rejected. 


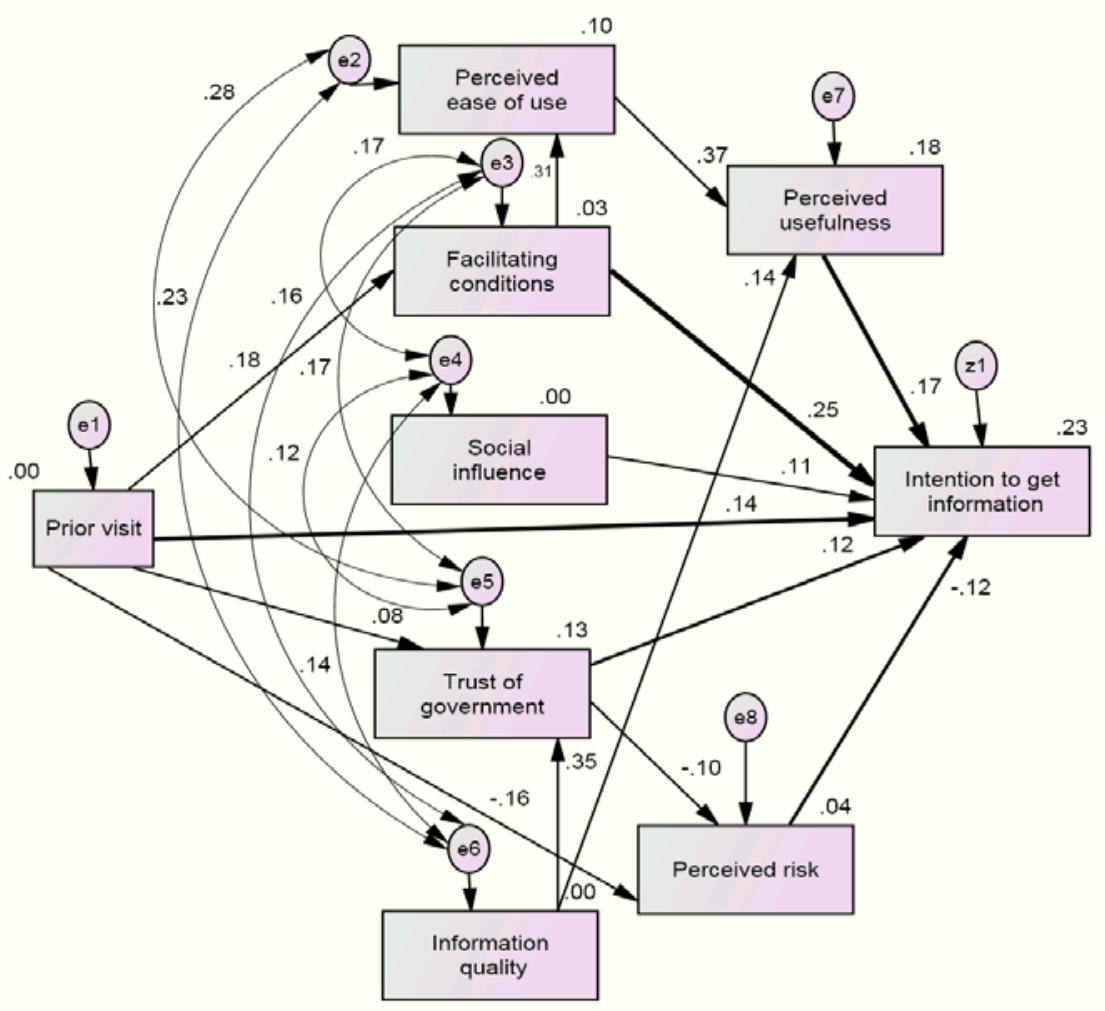

Figure 3. Path model for informational e-government

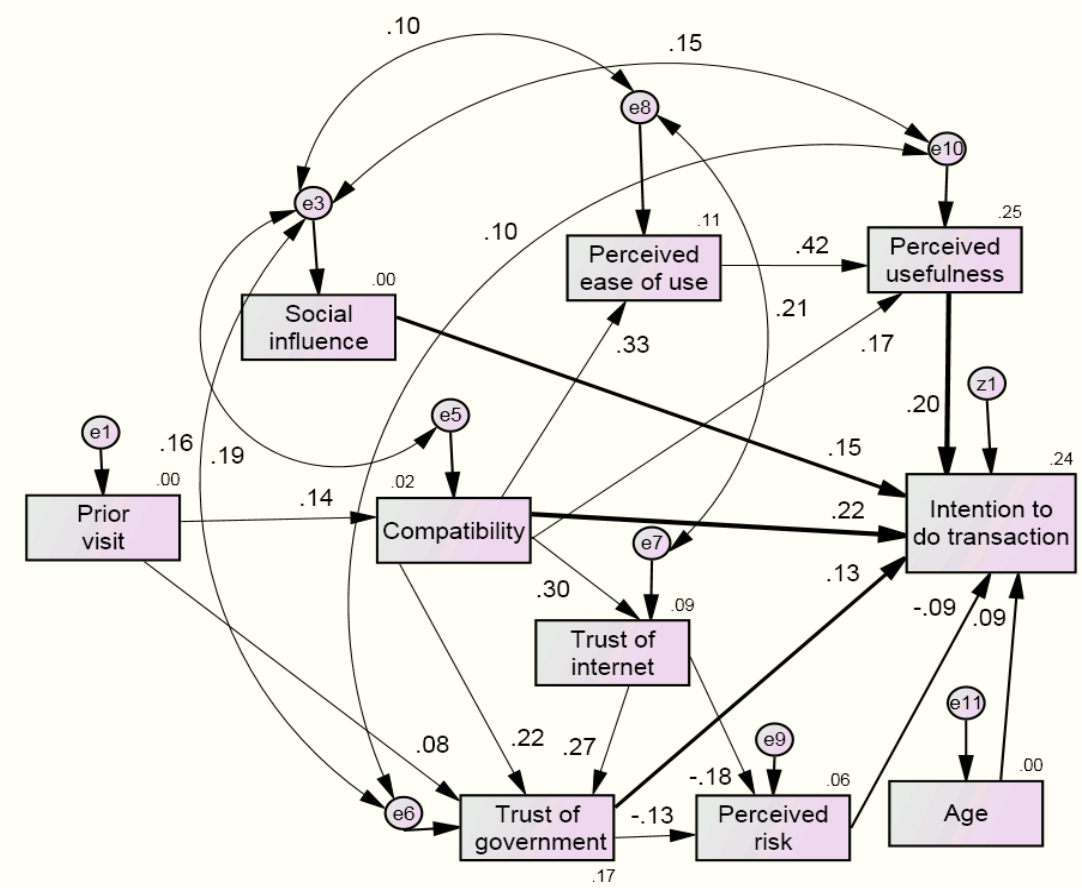

Figure 4. Path model for transactional e-government

The final step was to test the relation between intentions to use informational e-government with intentions to use transactional e-government. To do so, the two fitted models were 
combined and a path was drawn from intention to obtain information to intention to conduct transactions (Figure 5).

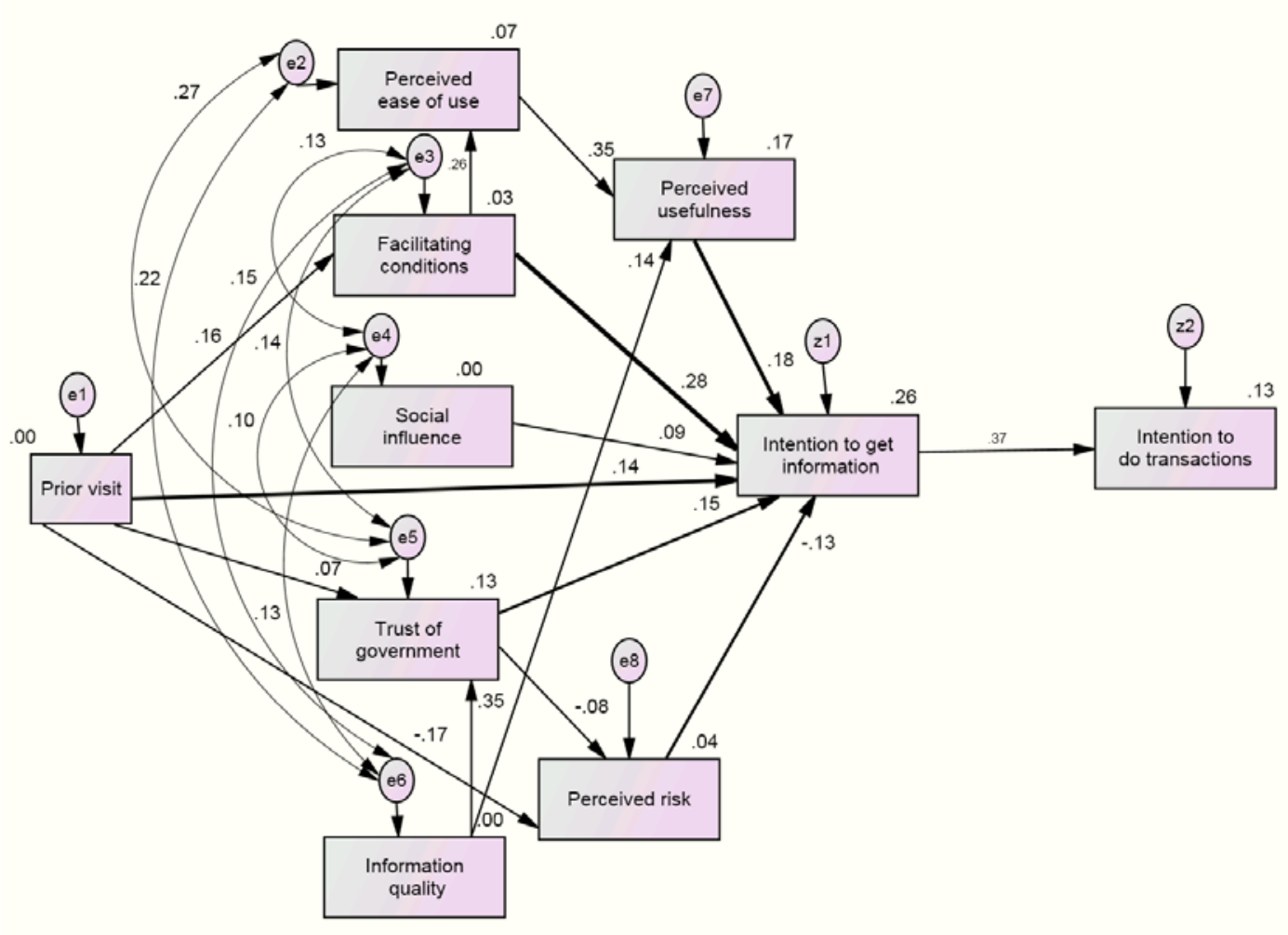

Figure 5. Path analysis testing the relationship between intention to seek information with the intention to conduct transactions

The analysis was performed and the modification indices revealed that the model did not fit the data well. The modification indices indicated that those variables that were duplicated on both sides of the model could be related. This was due to high collinearity between these repeated items on the two elements of the model. That is, these variables on each side were virtually measuring the same underlying concept. For example, perceived ease of use for both informational and transactional e-government measured the perception about the ease of using government websites to search for information and to conduct transactions. Since the objective was to see how much of the variance in the intention to use transactional $\mathrm{e}$ government was explained by the intention to use informational e-government, the predictor variables for the transactional model were removed and the analysis re-run. In order to fit the model the predictor variables were removed from the transactional model because they measured the same underlying concept within the informational model. Consequently the model fit the data and the results revealed that the relationship was significant $(\beta=0.37, p<$ 0.001). thus hypothesis 21 was supported suggesting that individuals who have a positive intention to use government websites to obtain information are more likely to also use govenment websites to conduct transactions with government. A summary of the results of hypotheses testing is provided in Table 2.

\section{Discussion}

This study investigated citizen attitudes to e-government adoption in the Kurdistan Region of Iraq with the aim of providing insight into the factors affecting the adoption of e-government within an emerging democratic state. In doing so, distinction was made between two types of e-government services; informational and transactional. In the conduct of this study it was recognised that not every individual in the region was likely to adopt e-government because of 
the reliance on systems that require users to be computer and Internet literate. Not all individuals in Kurdistan have these characteristics. Due to internal conflict within the region many people in Kurdistan have not had access to the necessary education and technology. Thus, in order to generate reliable results, the study focused on those who were most likely to become users of e-government services. To avoid having non-adopters participating in this study, it was decided to focus on university students and non-academic university staff to provide the sample for this study.

\begin{tabular}{|c|c|c|c|}
\hline Informational e-government & Support & Transactional e-government & Support \\
\hline $\begin{array}{l}\text { H1: Perceived usefulness has a } \\
\text { positive association. }\end{array}$ & Yes & $\begin{array}{l}\text { H10: Perceived ease of use has a } \\
\text { positive association. }\end{array}$ & No \\
\hline $\begin{array}{l}\text { H2: Perceived ease of use has a } \\
\text { positive association. }\end{array}$ & No & $\begin{array}{l}\text { H11: Perceived usefulness has a } \\
\text { positive association. }\end{array}$ & Yes \\
\hline $\begin{array}{l}\text { H3: Facilitating conditions has a } \\
\text { positive association. }\end{array}$ & Yes & $\begin{array}{l}\text { H12: Compatibility has a positive } \\
\text { association. }\end{array}$ & Yes \\
\hline $\begin{array}{l}\text { H4: Social influence has a positive } \\
\text { association. }\end{array}$ & Yes & $\begin{array}{l}\text { H13: Facilitating conditions has a } \\
\text { positive association. }\end{array}$ & No \\
\hline $\begin{array}{l}\text { H5: Perceived information quality } \\
\text { has a positive association. }\end{array}$ & No & $\begin{array}{l}\text { H14: Social influence has a positive } \\
\text { association. }\end{array}$ & Yes \\
\hline $\begin{array}{l}\text { H6: Trust in government has a } \\
\text { positive association. }\end{array}$ & Yes & $\begin{array}{l}\text { H15: Trust in government has a } \\
\text { positive association. }\end{array}$ & Yes \\
\hline $\begin{array}{l}\text { H7: Perceived risk has a negative } \\
\text { association. }\end{array}$ & Yes & $\begin{array}{l}\text { H16: Trust in the Internet has a } \\
\text { positive association. }\end{array}$ & No \\
\hline $\begin{array}{l}\text { H8: Trust in government would } \\
\text { indirectly associate with the } \\
\text { intention to use informational e- } \\
\text { government through its negative } \\
\text { relation with perceived risk. }\end{array}$ & Yes & $\begin{array}{l}\text { H17: Perceived risk has a negative } \\
\text { association. }\end{array}$ & Yes \\
\hline \multirow[t]{3}{*}{$\begin{array}{l}\text { H9: Perceived ease of use would } \\
\text { indirectly associate with the } \\
\text { intention to use informational e- } \\
\text { government through its positive } \\
\text { association with perceived } \\
\text { usefulness. }\end{array}$} & \multirow[t]{3}{*}{ Yes } & $\begin{array}{l}\text { H18: Trust in government would } \\
\text { indirectly associate with the } \\
\text { intention to use transactional e- } \\
\text { government through its negative } \\
\text { relation with perceived risk. }\end{array}$ & Yes \\
\hline & & $\begin{array}{l}\text { H19: Trust in the Internet would } \\
\text { indirectly associate with the } \\
\text { intention to use transactional e- } \\
\text { government through its negative } \\
\text { relation with perceived risk. }\end{array}$ & Yes \\
\hline & & $\begin{array}{l}\text { H20: Perceived ease of use would } \\
\text { indirectly associate with the } \\
\text { intention to use transactional e- } \\
\text { government through its positive } \\
\text { relation with perceived usefulness. }\end{array}$ & Yes \\
\hline \multicolumn{3}{|c|}{$\begin{array}{l}\text { H21: Positive association between intention to use informational e-government and the } \\
\text { intention to use transactional e-government. }\end{array}$} & Yes \\
\hline
\end{tabular}

Table 2. Summary of findings

Given this study background, our findings suggest that the same variables are likely to be important in determining citizens' intentions to adopt e-government services for both informational and transactional purposes. However, the magnitude of their importance may not be similar across both services, and it is likely to be stronger for transactional egovernment. The results of this study revealed that, except for perceived risk, the magnitude 
of the relationships been the independent variables and intention to use was stronger for transactional e-government than for informational e-government. This result supports the argument that transactional e-government is more complex and could be perceived by citizens to involve more risk in comparison to transactional e-government. Thus independent variables such as perceived usefulness, perceived ease of use, social influence and trust in government play a stronger role in predicting citizens' willingness to adopt transactional e-government compared to informational e-government.

\section{Conclusion}

The findings from this study have both theoretical and practical importance. Theoretically the findings confirm the contention that informational and transactional e-government services must be distinguished in order to more accurately identify the factors associated with the intention to adopt these different types of e-government services and so to make sound conclusions. In addition, this study was the first to investigate e-government adoption in the Kurdistan Region of Iraq which provides an important first step for future research in this region and contributes to the existing e-government literature concerning emerging democratic states.

In addition to these theoretical implications, the findings from this study also have implications for the Kurdistan Regional Government. The findings from this current study will assist the authorities in the region to predict whether its citizens are likely to adopt egovernment services, and what types of services they are likely to be more willing to adopt. In addition, the findings provide authorities with important insights into the factors that citizens are likely to consider when deciding to adopt this technology. This will enable the authorities to design and promote more effective e-government programs that align with citizens' expectations in order to increase citizen uptake.

Finally, the positive relationship between the intentions to use informational e-government with the intentions to use transactional e-government also provides practical value for authorities in the region. E-government in Kurdistan is still in the informational stage. Therefore, this finding suggests that designing and promoting the adoption of informational e-government services is likely to lead to greater rates of adoption of transactional egovernment services once available.

This study has several limitations which need to be mentioned. The first and probably the most important limitation was that sampling was limited to university students and staff and this group is not entirely representative of the general population in Kurdistan. However, at the time of this study, these participants were deemed to have the appropriate level of skill and access to consider using e-government services. Future research, however, may include a broader sample. A second limitation was that this study was conducted using a cross sectional approach. Future studies thus may consider a longitudinal approach in order to investigate citizens' perceptions before and after using e-government services. Finally, this study was conducted in Arbil; the capital city of the region. Therefore, including other cities in the region may provide further insights of practical and theoretical importance.

\section{References}

Ajzen, I. (1991). The theory of planned behaviour. Organizational Behaviour and Human Decision Processes, 50, 179-211.

Al Awadhi, S. \& Morris, A. (2008). The use of the UTAUT model in the adoption of e-government services in Kuwait. Proceedings of the 41st Hawaii International Conference on System Sciences, 1-10.

Almahamid, S., Mcadams, A. C., AL Kalaldeh, T. \& Al-Saeed, M. (2010). The relationship between perceived usefulness, perceived ease of use, perceived information quality, and intention to use e-government. Journal of Theoretical and Applied Information Technology, 11(1), 30-44. 
Al-Shafi, S. \& Weerakkody, V. (2010). Factors affecting e-government adoption in the state of Qatar. European and Mediterranean Conference on Information Systems. Retrieved from http://v-scheiner.brunel.ac.uk/ bitstream/2438/4395/ 1/ C101.pdf.

Alsaghier, H., Ford, M., Nguyen, A. and Hexel, R. (2009). Conceptualising citizen's trust in e-government: Application of Q Methodology. Electronic J ournal of e-Government, 7(4), 295-310.

Avgerou, C. \& Walsham, G. (Eds.) (2000). Information Technology in Context: Studies from the Perspective of Developing Countries. Ashgate Publishing: Aldershot, UK.

Bandura, A. (1986). Social foundations of thought and action: A social cognitive theory. New J ersey: Prentice-Hall, Inc.

Basu, S. (2004). E-government and developing countries: An overview. International Review of Law, Computers \& Technology, 18(1), 109-132.

Belanger, F. \&Carter, L. (2008). Trust and risk in e-government adoption. J ournal of Strategic Information Systems, 17, 165-176.

Berry, H. L. \&Welsh, J . A. (2010). Social capital and health in Australia: An overview from the household, income and labour dynamics in Australia survey. Social Science \& Medicine, 70, 588-596.

Bwalya, K. J. \& Mutula, S. M. (2014). E-Government: Implementation, Adoption and Synthesis in Developing Countries. Walter de Gruyter: berlin, Germany.

Carter, L. \& Belanger, F. (2004). Citizen adoption of electronic government initiatives. Proceedings of the 37th Hawaii International Conference on System Sciences, 1-10.

Carter, L. \& Belanger, F. (2005). The utilization of e-government services: citizen trust, innovation and acceptance factors. J ournal of Information Systems, 15, 5-25.

Chatfield, A. T. \& Alhujran, O. (2009). A cross-country comparative analysis of e-government service delivery among Arab countries. Information Technology for Development, 15(3), 151-170.

Chu, P. Y., Hsiao, N., Lee, F. W. \& Chen, C. W. (2004). Exploring success factors for Taiwan's government electronic tendering system: Behavioural perspectives from end users. Government Information Quarterly, 21, 219-234.

Dada, D. (2006). The failure of e-government in developing countries: A literature review. The Electronic J ournal of Information Systems in Developing Countries, 26(7), 1-10.

Davis, F. D. (1989). Perceived usefulness, perceived ease of use, and user acceptance of information technology. MIS Quarterly, 13(3), 319-340.

Davis, F. D., Bagozzi, R. P. \&Warshaw, P. R. (1989). User acceptance of computer technology: A comparison of two theoretical models. Management Science, 35(8), 982-1003.

Deci, E. L. (1972). Intrinsic motivation, extrinsic reinforcement, and inequity. Journal of Personality and Social Psychology, 22(1), 113-120.

Delafrooz, N., Paim, L. H. J . \& Khatibi, A. (2011). A research modeling to understand online shopping intention. Australian J ournal of Basic and Applied Sciences, 5(5), 70-77.

Delone, W. H. \& McLean, E. R. (1992). Information systems success: The quest for the dependent variable. Information Systems Research, 3(1), 60-95.

Ebrahim, Z. \& Irani, Z. (2005). E-government adoption: Architecture and barriers. Business Process Management J ournal, 11(5), 589-611.

Featherman, S. M. \& Pavlou, P. A. (2003). Predicting e-services adoption: A perceived risk facets perspective. International J ournal of Human-Computer Studies, 59, 451-474. 
Fishbein, M. \& Ajzen, I. (1975). Belief, attitude, intention and behaviour: An introduction to theory and research. Reading, MA: Addison-Wesley.

Fu, J . R., Farn, C. K. \& Chao, W. P. (2006). Acceptance of electronic tax filing: A study of taxpayer intentions. Information \& Management, 43, 109-126.

Gauld, R., Goldfinch, S. \& Horsburgh, S. (2010). Do they want it? Do they use it? The demand-side of e-government in Australia and New Zealand. Government Information Quarterly, 27, 177-186.

Gefen, D., Karahanna, E. \& Straub, D. W. (2003). Trust and TAM in online shopping: An integrated model. MIS Quarterly, 27(1), 51-90.

Gefen, D., Straub, D. W. \& Boudreau, M.-C. (2000). Structural equation modelling and regression: Guidelines for research practice. Communications of the Association for Information Systems, 4(7), 1-78.

Gregor, S., Imran, A. \& Turner, T. (2013). A 'sweet spot' change strategy for a least developed country: leveraging e-Government in Bangladesh. European J ournal of Information Systems advance online publication 9 J uly 2013; doi: 10.1057/ ejis.2013.14

Guha, J. \& Chakrabarti, B. (2014). Making e-government work: Adopting the network approach. Government Information Quarterly, 31(2), 327-336.

Gupta, B., Dasgupta, S. \& Gupta, A. (2008). Adoption of ICT in a government organization in a developing country: An empirical study. J ournal of Strategic Information Systems, 17, 140-154.

Heeks, R. (2002). Information systems and developing countries: Failure, success, and local improvisations. Information Society, 18(2), 101-112.

Horst, M., Kuttschreuter, M. \& Gutteling, J. M. (2007). Perceived usefulness, personal experience, risk perception and trust as determinants of adoption of e-government services in the Netherlands. Computers in Human Behaviour, 23, 1838-1852.

Kanat, I. E. \&Ozkan, S. (2009). Explaining citizen adoption of government to citizen services: A model based on theory of planned behaviour (TPB). European and Mediterranean Conference on Information Systems.

KRG IT Academy (2009). KRG Prime Minister Nechirvan Barzani's speech at launch of IT Academy, $10 \quad$ September 2009, http:/ / www.krg.org/a/ d.aspx?a=31432\&l=12\&r=268\&s=010000, [accessed 12 August 2014].

Kamal, M. M., Hackney, R. \& Sarwar, K. (2013). Investigating factors inhibiting e-government adoption in developing countries: the context of Pakistan.J ournal of Global Information Management, 21(4), pp. 77-102.

Kumar, V., Mukerji, B., Butt, I. \& Persaud, A. (2007). Factors for successful e-government adoption: A conceptual framework. The Electronic J ournal of e-Government, 5(1), 6376.

Lam, W. (2005). Barriers to e-government integration. The J ournal of Enterprise Information Management, 18(5), 511-530.

Lean, O. K., Zailani, S., Ramayah, T. \& Fernando, Y. (2009). Factors influencing intention to use e-government services among citizens in Malaysia. International J ournal of Information Management, 29, 458-475.

Lee, M. C. (2009). Factors influencing the adoption of internet banking: An integration of TAM and TPB with perceived risk and perceived benefit. Electronic Commerce Research and Applications, 8, 130-141. 
Lin, F., Fofanah, S. S. \&Liang, D. (2011). Assessing citizen adoption of e-government initiatives in Gambia: A validation of the technology acceptance model in information systems success. Government Information Quarterly, 28, 271-279.

Lu, Y., Cao, Y., Wang, B. \& Yang, S. (2011). A study on factors that affect users' behavioural intention to transfer usage from the offline to the online channel. Computers in Human Behaviour, 27, 355-364.

Mayer, R. C., Davis, J . H. \& Schoorman, F. D. (1995). An integrative model of organizational trust, Academy of Management Review, 20(3), 709-734.

McKnight, D. H., Choudhury, V. \& Kacmar, C. (2002). Developing and validating trust measures for e-commerce: An integrative typology. Information Systems Research, 13(3), 334-359.

Mkude, C. G. \& Wimmer, M. A. (2015). Studying Interdependencies of E-government Challenges in Tanzania along a Pestel Analysis. European Conference on Information Systems. Completed Research Papers. Paper 135.

Ndou, V. (2004). E-government for developing countries: Opportunities and challenges. The Electronic J ournal of Information Systems in Developing Countries, 18(1), 1-24.

Reddick, C. G. (2005). Citizen interaction with e-government: From the streets to servers? Government Information Quarterly, 22(1), 38-57.

Pavlou, P. A. (2003). Consumer acceptance of electronic commerce: Integrating trust and risk with the technology acceptance model. International J ournal of Electronic Commerce, 7(3), 101-134.

Prybutok, V. R., Zhang, X. \& Ryan, S. D. (2008). Evaluating leadership, IT quality, and net benefits in an e-government environment. Information \&Management, 45, 143-152.

Schaupp, L. C. \& Carter, L. (2005). E-voting: From apathy to adoption. The J ournal of Enterprise Information Management, 18(5), 586-601.

Suki, N. M. \& Ramayah, T. (2010). User acceptance of the e-government services in Malaysia: Structural equation modelling approach. Interdisciplinary J ournal of Information, Knowledge, and Management, 5, 395-413.

Taylor, S. \&Todd, P. (1995). Understanding information technology usage: A test of competing models. Information Systems Research, 6(2), 144-176.

Tung, L. L. \& Rieck, O. (2005). Adoption of electronic government services among business organizations in Singapore. J ournal of Strategic Information Systems, 14, 417-440.

Triandis, H. C. (1971). Attitude and attitude change. New York: J ohn Wiley \& Sons, Inc.

Vassilakis, C., Lepouras, G., Fraser, J., Haston, S. \& Georgiadis, P. (2005). Barriers to electronic service development. e-Service J ournal, 4(1), 41-63.

Venkatesh, V. \& Davis, F. D. (2000). A theoretical extension of the technology acceptance model: Four longitudinal field studies. Management Science, 45(2), 186-204.

Venkatesh, V., Morris, M. G., Davis, G. B. \&Davis, F. D. (2003). User acceptance of information technology: Toward a unified view. MIS Quarterly, 27(3), 425-478.

Wangpipatwong, S., Chutimaskul, W. \& Papasratorn, B. (2008). Understanding citizens continuance intention to use e-government website: A composite view of technology acceptance model and computer self-efficacy. The Electronic J ournal of e-Government, 6(1), 55-64.

Yaghoubi, N. M., Kord, B. \& Shakeri, R. (2010). E-government services and user acceptance: The unified models' perspective. European Journal of Economics, Finance and Administrative Sciences, (4), 36-49. 
Wang, Y. S. \& Shih, Y. W. (2009). Why do people use information kiosks? A validation of the unified theory of acceptance and use of technology. Government Information Quarterly, 26, 158-165.

Zhao, F., Collier, A. \&Deng, H. (2014). A multidimensional and integrative approach to study global digital divide and e-government development. Information Technology \&People, 27(1), 38-62 


\section{APPENDIX 1: SURVEY INSTRUMENT (ENGLISH VERSION)}

\section{E-government Description}

E-government: e-government the usage of Information and Communication Technologies (ICT) such as the Internet to deliver government services to citizens.

Types of e-government services: there are two basic types of services in e-government; Informational e-government and Transactional e-government.

Informational e-government: is the use of government websites by citizens to obtain information that they need or to download forms to apply for a service. For example, information about weather forecast, education related information, job notifications, the location of a government agency, the contact details for government employees, etc. This type of e-government services DOES NOT require the users to provide personal or financial information to the government agency.

Transactional e-government: is the use of the Internet to conduct transactions with government agencies online. For example, including online submission of hajj applications, registering child birth, registering death, renewing driver license, paying bills online, paying fines, applying for jobs etc. In this type of e-government services, in order to receive the service users MUST provide either personal information or financial information or both such as name, date of birth; address, bank details, phone number etc, and this information will be accessible by all government agencies.

Informational e-government already exists in Kurdistan as the majority of government agencies have launched their websites which allow users to obtain information, and in some instances to download forms. Transactional e-government, on the other hand, does not yet exist in Kurdistan. However, some agencies have introduced some limited transactional services. For example, the Ministry of Higher Education allows users to access information, to apply for higher degree courses and to apply for jobs electronically. The government has planned to develop its e-government services according to a 5-year plan (2011-2015).

This questionnaire consists of 3 parts. In the first part seeks demographic questions about yourself such as age, gender etc. In the second part, questions are asked regarding the use of e-government for information access only. In the third part, similar questions are asked regarding transactional e-government. Note that questions may sound similar, but they are different in wording so please do not be confused.

\section{Some examples of government websites available in Kurdistan}

http:// www.hawlergov.org/ kur/ subject.aspx?ID=468 (Parliament)

http://www.mojkurdistan.com/Kurdish_Malper.aspx (Ministry of J ustice)

http://www.zhenga.net/ english/index.php (Ministry of Environment)

http:// www.krgelectric.org (Ministry of Electricity)

http:/ / www.krp.org/ english/ default.aspx (Kurdistan Region Presidency)

http:// www.krg.org/ ?lngnr=12\&smap=01010000 (Kurdistan Regional Government)

http:// www.moc-krg.com/ English (Ministry of Transportation \& Communication)

http:/ / www.mhe-krg.org (Ministry of Higher Education \& Scientific Research) 
Section 1: Please tick the most appropriate box for the following items.

\section{Gender:}

\section{Male \\ Female}

2. What age group are you in?
(A). 15-19
(B). 20-24
(C). 25-29
(D). 30-34
(E). 35-39
(F). 40 and above

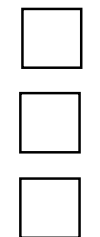

3. What course are you enrolled in (if you are student)? Or what is your educational level (if you are university employee)?
(A). Primary school qualification

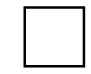
(B). High school qualification
(C). Undergraduate degree
(D). Post-graduate certificate or diploma
(E). Masters Qualification
(F). Doctorate
(H).Other (Please specify)

4. How many years of experience do you have with computers?
(A). Less than 1 year
(B). 1 to 3 years
(C). 4 to 6 years
(D). 7 to 9 years
(E). 10 and more

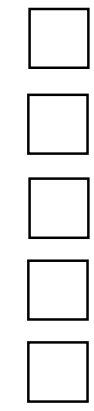

5. How many years of experience do you have with the Internet?
(A). Less than 1year
(B). 1 to 3 years
(C). 4 to 6 years
(D). 7 to 9 years
(E). 10 and more 


\section{Have you ever visited a government (Ministries) website prior to this survey?} Yes $\square$ No $\square$

\section{If yes, please explain what was the purpose of visit?}

Section 2: In this section we would like to know your opinion about Informational egovernment which is using government (Ministries) websites to obtain information only. Note that in this stage e-government can be used only to obtain information and to download forms, which DOES NOT require you to provide any personal and financial information. If you have visited government websites please answer the questions based on your experience.

Please circle the degree to which you agree with the following statements:

\section{Perceived usefulness}

\begin{tabular}{|c|l|c|c|c|c|c|}
\hline \multicolumn{2}{|c|}{} & $\begin{array}{c}\text { Strongly } \\
\text { disagree }\end{array}$ & Disagree & Neutral & Agree & $\begin{array}{c}\text { Strongly } \\
\text { agree }\end{array}$ \\
\hline 1 & $\begin{array}{l}\text { I find government websites useful } \\
\text { in my information access }\end{array}$ & 1 & 2 & 3 & 4 & 5 \\
\hline 2 & $\begin{array}{l}\text { Using government websites } \\
\text { enable me to obtain information I } \\
\text { need more quickly }\end{array}$ & 1 & 2 & 3 & 4 & 5 \\
\hline 3 & $\begin{array}{l}\text { Using government websites } \\
\text { increase my ability to get timely } \\
\text { information }\end{array}$ & 1 & 2 & 3 & 4 & 5 \\
\hline 4 & $\begin{array}{l}\text { Government websites enable me } \\
\text { to access information I need any } \\
\text { time anywhere }\end{array}$ & 1 & 2 & 3 & 4 & 5 \\
\hline 5 & $\begin{array}{l}\text { Overall, I believe that government } \\
\text { websites are useful in my } \\
\text { information access }\end{array}$ & 1 & 2 & 3 & 4 & 5 \\
\hline
\end{tabular}




\section{Perceived ease of use}

\begin{tabular}{|c|l|c|c|c|c|c|}
\hline \multicolumn{2}{|c|}{} & $\begin{array}{c}\text { Strongly } \\
\text { disagree }\end{array}$ & Disagree & Neutral & Agree & $\begin{array}{c}\text { Strongly } \\
\text { agree }\end{array}$ \\
\hline 1 & $\begin{array}{l}\text { My interaction with government } \\
\text { websites for information access } \\
\text { would be clear and } \\
\text { understandable }\end{array}$ & 1 & 2 & 3 & 4 & 5 \\
\hline 2 & $\begin{array}{l}\text { It would be easy for me to } \\
\text { navigate through government } \\
\text { websites and find the information } \\
\text { I need }\end{array}$ & 1 & 2 & 3 & 4 & 5 \\
\hline 3 & $\begin{array}{l}\text { It would be easy for me to become } \\
\text { skilful at using government } \\
\text { websites to find information and } \\
\text { download forms }\end{array}$ & 1 & 2 & 3 & 4 & 5 \\
\hline 4 & $\begin{array}{l}\text { I would find government websites } \\
\text { to be flexible to interact with }\end{array}$ & 1 & 2 & 3 & 4 & 5 \\
\hline 5 & $\begin{array}{l}\text { Overall, I believe that government } \\
\text { websites are easy to use for } \\
\text { obtaining information }\end{array}$ & 1 & 2 & 3 & 4 & 5 \\
\hline
\end{tabular}

\section{Perceived information quality}

\begin{tabular}{|c|l|c|c|c|c|c|}
\hline \multicolumn{2}{|l|}{} & $\begin{array}{c}\text { Strongly } \\
\text { disagree }\end{array}$ & Disagree & Neutral & Agree & $\begin{array}{c}\text { Strongly } \\
\text { agree }\end{array}$ \\
\hline 1 & $\begin{array}{l}\text { The information provided on } \\
\text { government websites are accurate }\end{array}$ & 1 & 2 & 3 & 4 & 5 \\
\hline 2 & $\begin{array}{l}\text { The information provided on } \\
\text { government websites are } \\
\text { complete }\end{array}$ & 1 & 2 & 3 & 4 & 5 \\
\hline 3 & $\begin{array}{l}\text { The information provided on } \\
\text { government websites are precise }\end{array}$ & 1 & 2 & 3 & 4 & 5 \\
\hline 4 & $\begin{array}{l}\text { Government websites provide } \\
\text { relevant information that I need }\end{array}$ & 1 & 2 & 3 & 4 & 5 \\
\hline 5 & $\begin{array}{l}\text { Government websites provide } \\
\text { timely information on their } \\
\text { websites }\end{array}$ & 1 & 2 & 3 & 4 & 5 \\
\hline 6 & $\begin{array}{l}\text { Overall, I believe that government } \\
\text { websites provide information } \\
\text { according to citizens need }\end{array}$ & 1 & 2 & 3 & 4 & 5 \\
\hline
\end{tabular}




\section{Facilitating conditions}

\begin{tabular}{|c|l|c|c|c|c|c|}
\hline \multicolumn{2}{|l|}{} & $\begin{array}{c}\text { Strongly } \\
\text { disagree }\end{array}$ & Disagree & Neutral & Agree & $\begin{array}{c}\text { Strongly } \\
\text { agree }\end{array}$ \\
\hline 1 & $\begin{array}{l}\text { I have the resources (hardware \& } \\
\text { software) necessary to use } \\
\text { government websites to obtain } \\
\text { information }\end{array}$ & 1 & 2 & 3 & 4 & 5 \\
\hline 2 & $\begin{array}{l}\text { I have the skills necessary to use } \\
\text { government websites to obtain } \\
\text { information I need }\end{array}$ & 1 & 2 & 3 & 4 & 5 \\
\hline 3 & $\begin{array}{l}\text { I have the knowledge necessary } \\
\text { to access government websites to } \\
\text { obtain information I need }\end{array}$ & 1 & 2 & 3 & 4 & 5 \\
\hline 4 & $\begin{array}{l}\text { Overall, I believe that I have the } \\
\text { conditions necessary to access } \\
\text { government websites and obtain } \\
\text { information }\end{array}$ & 1 & 2 & 3 & 4 & 5 \\
\hline
\end{tabular}

\section{Social influence}

\begin{tabular}{|c|l|c|c|c|c|c|}
\hline \multicolumn{2}{|c|}{} & $\begin{array}{l}\text { Strongly } \\
\text { disagree }\end{array}$ & Disagree & Neutral & Agree & $\begin{array}{c}\text { Strongly } \\
\text { agree }\end{array}$ \\
\hline 1 & $\begin{array}{l}\text { People who influence my } \\
\text { behaviour will have an impact on } \\
\text { my decision to use government } \\
\text { websites to access information }\end{array}$ & 1 & 2 & 3 & 4 & 5 \\
\hline 2 & $\begin{array}{l}\text { People who are important to me } \\
\text { will influence my decision to use } \\
\text { informational e-government }\end{array}$ & 1 & 2 & 3 & 4 & 5 \\
\hline 3 & $\begin{array}{l}\text { My friends and colleagues will } \\
\text { have an influence on my decision } \\
\text { to use informational e- } \\
\text { government }\end{array}$ & 1 & 2 & 3 & 4 & 5 \\
\hline $\begin{array}{l}\text { Using government websites to } \\
\text { access information by a large } \\
\text { proportion of people around me } \\
\text { will influence my intention to use } \\
\text { it }\end{array}$ & 1 & 2 & 3 & 4 & 5 \\
\hline
\end{tabular}




\section{Trust in government}

\begin{tabular}{|c|l|c|c|c|c|c|}
\hline \multicolumn{2}{|l|}{} & $\begin{array}{c}\text { Strongly } \\
\text { disagree }\end{array}$ & Disagree & Neutral & Agree & $\begin{array}{c}\text { Strongly } \\
\text { agree }\end{array}$ \\
\hline 1 & $\begin{array}{l}\text { In my opinion, government } \\
\text { agencies can be trusted in } \\
\text { providing good information on } \\
\text { their websites }\end{array}$ & 1 & 2 & 3 & 4 & 5 \\
\hline 2 & $\begin{array}{l}\text { I believe that government agencies } \\
\text { are honest in providing } \\
\text { information on their websites }\end{array}$ & 1 & 2 & 3 & 4 & 5 \\
\hline 3 & $\begin{array}{l}\text { I think that government agencies } \\
\text { in Kurdistan are trustworthy }\end{array}$ & 1 & 2 & 3 & 4 & 5 \\
\hline 4 & $\begin{array}{l}\text { Overall, I think that I can trust } \\
\text { government agencies as the } \\
\text { provider of governmental } \\
\text { information }\end{array}$ & 1 & 2 & 3 & 4 & 5 \\
\hline
\end{tabular}

\section{Perceived risk}

\begin{tabular}{|l|l|c|c|c|c|c|}
\hline \multicolumn{2}{|c|}{} & $\begin{array}{l}\text { Strongly } \\
\text { disagree }\end{array}$ & Disagree & Neutral & Agree & $\begin{array}{c}\text { Strongly } \\
\text { agree }\end{array}$ \\
\hline 1 & $\begin{array}{l}\text { In my opinion the decision to use } \\
\text { government websites to obtain } \\
\text { information is a risky decision }\end{array}$ & 1 & 2 & 3 & 4 & 5 \\
\hline 2 & $\begin{array}{l}\text { I believe that using government } \\
\text { websites to gather information is } \\
\text { risky }\end{array}$ & 1 & 2 & 3 & 4 & 5 \\
\hline 3 & $\begin{array}{l}\text { Overall, I believe using e- } \\
\text { government for informational } \\
\text { purposes is risky }\end{array}$ & 1 & 2 & 3 & 4 & 5 \\
\hline
\end{tabular}

\section{Behavioural intention to get information}

\begin{tabular}{|c|l|c|c|c|c|c|}
\hline \multicolumn{2}{|c|}{} & $\begin{array}{c}\text { Strongly } \\
\text { disagree }\end{array}$ & Disagree & Neutral & Agree & $\begin{array}{c}\text { Strongly } \\
\text { agree }\end{array}$ \\
\hline 1 & $\begin{array}{l}\text { I have the intention to use } \\
\text { government websites to obtain } \\
\text { information }\end{array}$ & 1 & 2 & 3 & 4 & 5 \\
\hline 2 & $\begin{array}{l}\text { I predict that I will continue using } \\
\text { government websites to obtain } \\
\text { information }\end{array}$ & 1 & 2 & 3 & 4 & 5 \\
\hline 3 & $\begin{array}{l}\text { I expect that I will use and } \\
\text { continue to use government } \\
\text { websites to obtain information }\end{array}$ & 1 & 2 & 3 & 4 & 5 \\
\hline
\end{tabular}


Section 3: In this section we would like to understand about your opinion regarding Transactional e-government. Please rate the following questions on a scale of 1 to 5 that best describes your opinion about e-services (conducting transaction with government online). Please note that this section is concerned with using transactional e-government, which is using the Internet to transact with government where you MUST provide personal or financial information or both to government agencies in order to receive the service. For example, applying for jobs, renewing driver licence, applying for a passport, applying for marriage certificate, paying bills electronically.

Please circle the degree to which you agree with the following statements:

\section{Perceived usefulness}

\begin{tabular}{|c|l|c|c|c|c|c|}
\hline \multicolumn{2}{|c|}{} & $\begin{array}{l}\text { Strongly } \\
\text { disagree }\end{array}$ & Disagree & Neutral & Agree & $\begin{array}{c}\text { Strongly } \\
\text { agree }\end{array}$ \\
\hline 1 & $\begin{array}{l}\text { I believe that using transactional } \\
\text { e-government will enable me to } \\
\text { complete transactions with } \\
\text { government more quickly }\end{array}$ & 1 & 2 & 3 & 4 & 5 \\
\hline 2 & $\begin{array}{l}\text { Transactional e- government will } \\
\text { increase my effectiveness by } \\
\text { lowering travelling and queuing } \\
\text { time }\end{array}$ & 1 & 2 & 3 & 4 & 5 \\
\hline 3 & $\begin{array}{l}\text { Using transactional e- } \\
\text { government will enable me to } \\
\text { access more government services } \\
\text { than would otherwise possible }\end{array}$ & 1 & 2 & 3 & 4 & 5 \\
\hline & $\begin{array}{l}\text { Using the Internet to interact } \\
\text { with government will enable me } \\
\text { to do business with the } \\
\text { government anytime not limited } \\
\text { to regular business hours. }\end{array}$ & 1 & 2 & 3 & 4 & 5 \\
\hline 5 & $\begin{array}{l}\text { Overall, I would find } \\
\text { transactional e-government } \\
\text { useful in my transaction with } \\
\text { government }\end{array}$ & 1 & 2 & 3 & 4 & 5 \\
\hline
\end{tabular}




\section{Perceived ease of use}

\begin{tabular}{|c|l|c|c|c|c|c|}
\hline \multicolumn{2}{|c|}{} & $\begin{array}{c}\text { Strongly } \\
\text { disagree }\end{array}$ & Disagree & Neutral & Agree & $\begin{array}{c}\text { Strongly } \\
\text { agree }\end{array}$ \\
\hline 1 & $\begin{array}{l}\text { Learning to use e-government to } \\
\text { transact with government will be } \\
\text { easy for me }\end{array}$ & 1 & 2 & 3 & 4 & 5 \\
\hline 2 & $\begin{array}{l}\text { My interaction with government } \\
\text { websites for transaction will be } \\
\text { clear and understandable }\end{array}$ & 1 & 2 & 3 & 4 & 5 \\
\hline 3 & $\begin{array}{l}\text { It will be easy for me to become } \\
\text { skilful at using government } \\
\text { websites to conduct transaction } \\
\text { with government }\end{array}$ & 1 & 2 & 3 & 4 & 5 \\
\hline 4 & $\begin{array}{l}\text { I will find transactional e- } \\
\text { government services to be flexible } \\
\text { to interact with }\end{array}$ & 1 & 2 & 3 & 4 & 5 \\
\hline 5 & $\begin{array}{l}\text { Overall, I believe that using e- } \\
\text { government services for } \\
\text { transaction with government will } \\
\text { be easy for me }\end{array}$ & 1 & 2 & 3 & 4 & 5 \\
\hline
\end{tabular}

\section{Social Influence}

\begin{tabular}{|c|l|c|c|c|c|c|}
\hline \multicolumn{2}{|c|}{} & $\begin{array}{c}\text { Strongly } \\
\text { disagree }\end{array}$ & Disagree & Neutral & Agree & $\begin{array}{c}\text { Strongly } \\
\text { agree }\end{array}$ \\
\hline 1 & $\begin{array}{l}\text { People who influence my } \\
\text { behaviour will have an impact on } \\
\text { my decision to use government } \\
\text { websites to transact with } \\
\text { government }\end{array}$ & 1 & 2 & 3 & 4 & 5 \\
\hline 2 & $\begin{array}{l}\text { People who are important to me } \\
\text { will influence my decision to use } \\
\text { e-government services to transact } \\
\text { with government }\end{array}$ & 1 & 2 & 3 & 4 & 5 \\
\hline 3 & $\begin{array}{l}\text { My friends and colleagues will } \\
\text { influence my decision to use e- } \\
\text { government services to transact } \\
\text { with government }\end{array}$ & 1 & 2 & 3 & 4 & 5 \\
\hline & $\begin{array}{l}\text { Using e-government for doing } \\
\text { transaction with government by a } \\
\text { large proportion of people around } \\
\text { me will influence my decision to } \\
\text { use it }\end{array}$ & 1 & 2 & 3 & 4 & 5 \\
\hline
\end{tabular}




\section{Facilitating conditions}

\begin{tabular}{|c|l|c|c|c|c|c|}
\hline \multicolumn{2}{|c|}{} & $\begin{array}{c}\text { Strongly } \\
\text { disagree }\end{array}$ & Disagree & Neutral & Agree & $\begin{array}{c}\text { Strongly } \\
\text { agree }\end{array}$ \\
\hline 1 & $\begin{array}{l}\text { I believe I have the resources } \\
\text { (hardware \& software) necessary } \\
\text { to access government websites } \\
\text { for conducting transactions with } \\
\text { government }\end{array}$ & 1 & 2 & 3 & 4 & 5 \\
\hline 2 & $\begin{array}{l}\text { I think I have the knowledge } \\
\text { necessary to use government } \\
\text { websites for conducting } \\
\text { transactions with government }\end{array}$ & 1 & 2 & 3 & 4 & 5 \\
\hline 3 & $\begin{array}{l}\text { I believe I have the skills } \\
\text { necessary to use t e-government } \\
\text { services for conducting } \\
\text { transaction with government } \\
\text { agencies }\end{array}$ & 1 & 2 & 3 & 4 & 5 \\
\hline & $\begin{array}{l}\text { Overall, I believe that I have the } \\
\text { conditions necessary to use state } \\
\text { government websites to conduct } \\
\text { transactions with government } \\
\text { agencies online }\end{array}$ & 1 & 2 & 3 & 4 & 5 \\
\hline
\end{tabular}

\section{Compatibility}

\begin{tabular}{|c|l|c|c|c|c|c|}
\hline \multicolumn{2}{|c|}{} & $\begin{array}{c}\text { Strongly } \\
\text { disagree }\end{array}$ & Disagree & Neutral & Agree & $\begin{array}{c}\text { Strongly } \\
\text { agree }\end{array}$ \\
\hline 1 & $\begin{array}{l}\text { I think using the Internet will fit } \\
\text { with the way that I like to } \\
\text { transact with government }\end{array}$ & 1 & 2 & 3 & 4 & 5 \\
\hline 2 & $\begin{array}{l}\text { Using the Internet to transact } \\
\text { with government agencies is what } \\
\text { I like to do }\end{array}$ & 1 & 2 & 3 & 4 & 5 \\
\hline 3 & $\begin{array}{l}\text { Using the Internet to transact } \\
\text { with government agencies will fit } \\
\text { into my lifestyle }\end{array}$ & 1 & 2 & 3 & 4 & 5 \\
\hline 4 & $\begin{array}{l}\text { I prefer face-to-face transaction } \\
\text { with government agencies }\end{array}$ & 1 & 2 & 3 & 4 & 5 \\
\hline
\end{tabular}


Trust in the Internet

\begin{tabular}{|c|l|c|c|c|c|c|}
\hline \multicolumn{2}{|l|}{} & $\begin{array}{c}\text { Strongly } \\
\text { disagree }\end{array}$ & Disagree & Neutral & Agree & $\begin{array}{c}\text { Strongly } \\
\text { agree }\end{array}$ \\
\hline 1 & $\begin{array}{l}\text { I think the Internet has enough } \\
\text { safeguards to make me feel } \\
\text { comfortable using it to transact } \\
\text { with state government agencies } \\
\text { online }\end{array}$ & 1 & 2 & 3 & 4 & 5 \\
\hline $\begin{array}{l}\text { I feel assured that legal and } \\
\text { technological structures } \\
\text { adequately protect me from } \\
\text { problems on the Internet }\end{array}$ & 1 & 2 & 3 & 4 & 5 \\
\hline 3 & $\begin{array}{l}\text { In general, the Internet is now a } \\
\text { robust and safe environment in } \\
\text { which to transact with state } \\
\text { government agencies }\end{array}$ & 1 & 2 & 3 & 4 & 5 \\
\hline
\end{tabular}

\section{Trust in government}

\begin{tabular}{|c|l|c|c|c|c|c|}
\hline \multicolumn{2}{|c|}{} & $\begin{array}{c}\text { Strongly } \\
\text { disagree }\end{array}$ & Disagree & Neutral & Agree & $\begin{array}{c}\text { Strongly } \\
\text { agree }\end{array}$ \\
\hline 1 & $\begin{array}{l}\text { I think I can trust state } \\
\text { government agencies in dealing } \\
\text { with my personal and financial } \\
\text { information }\end{array}$ & 1 & 2 & 3 & 4 & 5 \\
\hline 2 & $\begin{array}{l}\text { State government agencies can be } \\
\text { trusted to carry out online } \\
\text { transactions faithfully }\end{array}$ & 1 & 2 & 3 & 4 & 5 \\
\hline 3 & $\begin{array}{l}\text { In my opinion, state government } \\
\text { agencies are trustworthy }\end{array}$ & 1 & 2 & 3 & 4 & 5 \\
\hline 4 & $\begin{array}{l}\text { Overall, I trust state government } \\
\text { agencies to keep my best interest } \\
\text { in mind when doing online } \\
\text { transactions }\end{array}$ & 1 & 2 & 3 & 4 & 5 \\
\hline
\end{tabular}

\section{Perceived risk}

\begin{tabular}{|c|l|c|c|c|c|c|}
\hline \multicolumn{2}{|c|}{} & $\begin{array}{c}\text { Strongly } \\
\text { disagree }\end{array}$ & Disagree & Neutral & Agree & $\begin{array}{c}\text { Strongly } \\
\text { agree }\end{array}$ \\
\hline 1 & $\begin{array}{l}\text { Using e-government to transact } \\
\text { with government agencies may } \\
\text { cause my personal and financial } \\
\text { information to be stolen }\end{array}$ & 1 & 2 & 3 & 4 & 5 \\
\hline 2 & $\begin{array}{l}\text { The decision of whether to use } \\
\text { transactional } \\
\text { e-government services is risky }\end{array}$ & 1 & 2 & 3 & 4 & 5 \\
\hline 3 & $\begin{array}{l}\text { In general, I believe conducting } \\
\text { transactions with government } \\
\text { online is risky }\end{array}$ & 1 & 2 & 3 & 4 & 5 \\
\hline
\end{tabular}




\section{Behavioural intention to do transactions}

\begin{tabular}{|c|l|c|c|c|c|c|}
\hline \multicolumn{2}{|c|}{} & $\begin{array}{c}\text { Strongly } \\
\text { disagree }\end{array}$ & Disagree & Neutral & Agree & $\begin{array}{c}\text { Strongly } \\
\text { agree }\end{array}$ \\
\hline 1 & $\begin{array}{l}\text { I intend to use e-government to } \\
\text { do transaction with government } \\
\text { agencies when it becomes } \\
\text { available }\end{array}$ & 1 & 2 & 3 & 4 & 5 \\
\hline 2 & $\begin{array}{l}\text { I plan to use e-government to } \\
\text { transact with government when } \\
\text { it becomes available }\end{array}$ & 1 & 2 & 3 & 4 & 5 \\
\hline 3 & $\begin{array}{l}\text { Using e-government services } \\
\text { over the web to transact with } \\
\text { government is something that I } \\
\text { would do }\end{array}$ & 1 & 2 & 3 & 4 & 5 \\
\hline
\end{tabular}

\section{Thank you for your participation in this survey}

Copyright: (C) 2015 Ahmad \& Campbell. This is an open-access article distributed under the terms of the Creative Commons Attribution-NonCommercial 3.0 Australia License, which permits non-commercial use, distribution, and reproduction in any medium, provided the original author and AJ IS are credited.

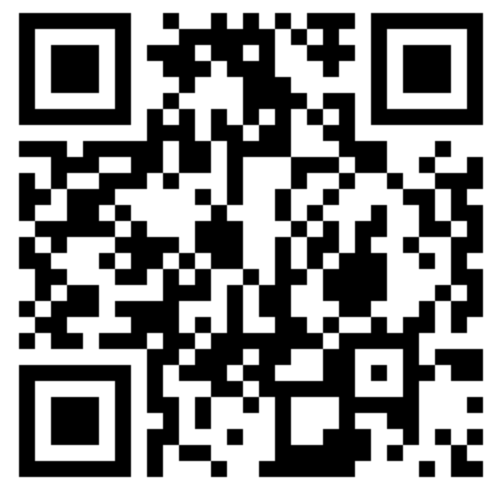

